\title{
A low-cost, sustainable, second generation system for surveillance of people living with HIV in Spain: 10 -year trends in behavioural and clinical indicators, 2002 to 2011
}

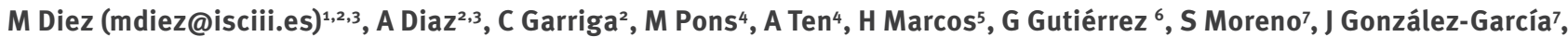
A M Barrios ${ }^{7}$, S Arponen7, M T García 7 , M C Royo ${ }^{8}$, J Toledo9, G González ${ }^{10}$, R Aranguren ${ }^{11}$, A Izquierdo ${ }^{12}$, L J Viloria ${ }^{13}$, E Martínez ${ }^{14}$, L Elizalde $^{15}$, D Castrillejo ${ }^{16}$, I López ${ }^{17}$, C Redondo ${ }^{18}$, A Cano ${ }^{18}$, the Hospital Survey Study Group ${ }^{19}$

1. Plan Nacional sobre el Sida. S.G. de Promoción de la Salud y Epidemiología. Ministerio de Sanidad, Servicios Sociales e Igualdad (National Plan on AIDS. Subdirectorate of Health Promotion and Epidemiology. Ministry of Health, Social Services and Equality), Madrid, Spain

2. Área de Vigilancia del VIH y comportamientos de riesgo. Centro Nacional de Epidemiología. Instituto de Salud Carlos III (Unit of HIV Surveillance and Behavioural Monitoring. National Centre of Epidemiology, Carlos III Health Institute), Madrid, Spain

3. Centro de Investigación Biomédica en Red de Epidemiología y Salud Pública (CIBERESP) (Network of Biomedical Research Centers Epidemiology and Public Health), Madrid, Spain

4. Plan sida, Servicio de planes, programas y estrategias de salud, Subdirección general de promoción y prevención de salud, D.G. de Salud Pública, Conselleria de Sanitat (AIDS Plan, Service of Plans, Programmes and Strategies on Health, Subdirectorate of Health Promotion and Prevention, Directorate Ge

5. Servicio de Vigilancia Epidemiológica y Enfermedades Transmisibles, D.G. de Salud Pública, Consejería de Sanidad (Service of Epidemiological Surveillance and Transmissible Diseases, Directorate General of Public Health, Regional Health Department), Castilla y León, Spain

6. Servicio de Epidemiología, D.G. de Salud Pública. Consejería de Sanidad (Service of Epidemiology, Directorate General of Public Health, Regional Health Department), Castilla-La Mancha, Spain

7. Comunidad Autónoma de Madrid (Autonomous Region of Madrid), Madrid, Spain

8. Servicio de Evaluación de la Salud y Programas, D.G. de Salud Pública, Consejería de Sanidad (Service of Health Evaluation and Programmes, Directorate General of Public Health, Regional Health Department), Asturias, Spain

9. Coordinación de VIH/sida, Servicio de Promoción de la Salud y Prevención de la Enfermedad, D.G. de Salud Pública (HIV/ AIDS Coordination, Service of Health Promotion and Prevention, Directorate General of Public Health), Aragón, Spain

10. Oficina de Coordinación VIH de Extremadura, Servicio de Participación Comunitaria en Salud, D.G. de Salud Pública, Servicio extremeño de salud (HIV coordination Office of Extremadura, Service of Community Participation, Directorate General of Public Health, Regional Health Department), Extremadura,

11. Coordinación Autonómica de Drogas y de la Estrategia de Sida, D.G. de Salut Pública i Consum, Conselleria de Salut, Família i Bienestar Social (Regional Coordination of Drugs and AIDS Strategy, Directorate General of Public Health, Regional Health Family and Social Welfare Department), Baleares, Spa

12. Servicio de Epidemiologia y Promoción de la salud, D.G. de Salud Pública, Servicio Canario de la Salud (Service of Epidemiology and Health Promotion, Directorate General of Public Health, Regional Health Department), Canarias, Spain

13. Sección de Vigilancia Epidemiológica, D.G. de Salud Pública (Section of Epidemiological Surveillance, Directorate General of Public Health, Regional Health Department), Cantabria, Spain

14. Sección de Vigilancia Epidemiológica y Control de Enfermedades Transmisibles, D.G de Salud Pública y Consumo,

Consejería de Salud y Servicios Sociales (Section of Epidemiological Surveillance and Control of Transmissible Diseases, Directorate General of Public Health and Consumer Affairs, Regional H

15. Sección de Promoción de Salud, Instituto de Salud Pública y Laboral (Section of Health Promotion, Public Health Institute of Navarre), Navarra, Spain

16. Servicio de Epidemiología, D.G. de Sanidad y Consumo, Consejería de Bienestar Social y Sanidad,(Service of Epidemiology, Directorate General of Health and Consumer Affairs, Regional Social Welfare and Health Department), Melilla, Spain

17. Servicio de prevención y epidemiología del Plan sobre Sida, Consejería de Sanidad y Consumo (Service of AIDS prevention and Epidemiology, Regional Health and Consumer Affairs Department), Ceuta, Spain

18. Comunidad Autónoma de Murcia (Autonomous Region of Murcia), Murcia, Spain

19. The members of the Hospital Survey Study Group are listed at the end of the article

Citation style for this article:

Diez M, Garriga C, Pons M, Ten A, Marcos H, Gutiérrez G, Moreno S, González-García J, Barrios AM, Arponen S, García MT, Royo MC, Toledo J, González G,

Aranguren R, Izquierdo A, Viloria LJ, Martínez E, Elizalde L, Castrillejo D, López I, Redondo C, Cano A, the Hospital Survey Study Group . A low-cost, sustainable, second generation system for surveillance of people living with HIV in Spain: 10-year trends in behavioural and clinical indicators, 2002 to 2011 . Euro Surveill. 2014;19(20): pii=20805. Available online: http://www.eurosurveillance.org/ViewArticle.aspx?Articleld=20805

A second-generation surveillance system of people infected with human immunodeficiency virus (HIV) has been implemented in Spain. Behavioural and clinical data were collected between 2002 and 2011 through an annual one-day, cross-sectional survey in public hospitals, including all in- and outpatients receiving HIVrelated care on the survey day. Mean age increased over time (from 38.7 years in 2002 to 43.8 years in
2011) and $68.4 \%$ of the 7,205 subjects were male. The proportion of migrants increased from $6.1 \%$ to $15.9 \%$, while people who inject or used to inject drugs (PWID and Ex-PWID) decreased and men who have sex with men (MSM) and heterosexuals increased. Unprotected intercourse at last sex increased among MSM and PWID/Ex-PWID. Patients receiving antiretroviral treatment increased significantly from $76.0 \%$ to 
$88.2 \%$ as did those with $\mathrm{CD}_{4} \mathrm{~T}$-cell counts $\geq 350$ (from $48.2 \%$ to $66.9 \%$ ) and viral copies $<200$ (from $47.0 \%$ to $85.2 \%)$. HIV-infected people with hepatitis C virus RNA decreased from $36.0 \%$ in 2004 to $29.9 \%$ in 2011, while those with $\mathrm{HBsAg}$ remained stable at around $4.4 \%$. Implementation of a low-cost, sustainable system for second-generation surveillance in people living with HIV is feasible. In Spain, the information obtained has helped to define and refine public health policy and document treatment effectiveness.

\section{Introduction}

Second generation surveillance for human immunodeficiency virus (HIV) is the systematic, ongoing collection of biomedical and behavioural information in all groups of interest for HIV, with the objective of monitoring changes in risk behaviour and other factors that influence the occurrence of HIV infection [1]. Implementation of second generation surveillance in people living with HIV (PLWH) is important because, if they engage in risk behaviours, they can transmit the infection to others and expose themselves to re-infection with HIV or infection with other pathogens.

Ecological studies have shown an inverse relation between uptake of HIV treatment by PLWH and new HIV diagnoses [2,3], and early treatment has recently been proven to be a highly efficacious measure to prevent HIV transmission to HIV-negative sexual partners [4]. However, even in high-income countries, linkage of HIV-positive individuals to treatment and viral load suppression is not easy to achieve [5,6]. This underlines the importance of obtaining data on treatment access and effectiveness in PLWH in order to document progress towards the control of the HIV epidemic.

In 2009, the European Centre for Disease Prevention and Control (ECDC) commissioned a mapping study of behavioural surveillance activities in European Union/ European Economic Area (EU/EEA) countries. Despite the fact that PLWH are the major group of interest for the prevention and control of further spread of HIV, the results showed that behavioural surveillance activities were very scarce among this group and pointed out the challenges in collecting this type of information in a sustainable way due to difficulties in sampling this population and following up over time. In addition, this report suggested relevant indicators to be collected for PLWH which included not only behavioural information but also clinical data such as viral load or $\mathrm{CD}_{4} \mathrm{~T}$-cell count [7].

In 2011, between 130,000 and 160,000 people in Spain were estimated to be living with HIV, around $30 \%$ of whom did not know their HIV status, and more than 90,000 were reported to be receiving highly active anti-retroviral therapy (HAART) $[8,9]$.

Starting in 1996, when HAART was scaled up in the country, it was decided to set up a population-based information system, the 'Encuesta hospitalaria de pacientes infectados con VIH (EH)' (Hospital survey of patients infected with HIV), with the objective of obtaining up-to-date clinical and epidemiological information on PLWH. This survey has since been carried out yearly, except on two occasions, and a report of its results is published to inform clinical and public health practice [10]. Over time, the EH has been modified to include other information of interest, and in 2002, questions on sexual and other risk behaviours were introduced.

The EH is the only population-based source of clinical and behavioural information that we are aware of in the European setting which has allowed the systematic collection of information on PLWH over time. Here we present trend data from 2002 to 2011 on key behavioural and clinical indicators among PLWH in Spain.

\section{Methods}

The $\mathrm{EH}$ is an annual one-day cross-sectional survey that collects socio-demographic, epidemiological, behavioural, clinical and preventive measures such as vaccinations on all PLWH attending general public hospitals for HIV-related care on the day of the survey; both inpatients and outpatients are included. Because of limited resources, HIV-infected people who receive care at the hospital for reasons other than HIV are excluded.

Since a sampling frame for PLWH does not exist, the study was performed in public hospitals. The rationale behind this was that HIV care in Spain is hospital-based and free of charge, and all HIV-infected persons living in the catchment area of a public hospital receive care at that hospital; catchment areas are geographically defined and the population covered by a particular hospital is known, thus allowing coverage calculations; 'population coverage' is defined as the proportion of the total population living in a particular region/s included in the participating hospitals' catchment

\section{TABLE 1}

Hospitals participating in the annual one-day crosssectional survey, Spain, 2002-2011

\begin{tabular}{|l|c|c|}
\hline Year & $\begin{array}{c}\text { Hospitals providing } \\
\text { care for HIV in the } \\
\text { study area }\end{array}$ & $\begin{array}{c}\text { Participating } \\
\text { hospitals } \\
\text { n (\%) }\end{array}$ \\
\hline 2002 & 111 & $79(71)$ \\
\hline 2003 & 120 & $86(72)$ \\
\hline 2004 & 112 & $77(69)$ \\
\hline 2006 & 115 & $67(58)$ \\
\hline 2007 & 106 & $77(73)$ \\
\hline 2008 & 125 & $81(65)$ \\
\hline 2009 & 127 & $87(69)$ \\
\hline 2010 & 125 & $88(70)$ \\
\hline 2011 & 124 & $91(73)$ \\
\hline
\end{tabular}

HIV: human immunodeficiency virus.

a Participating regions varied from 13 in 2007 and 2011 to 16 in 2003 (of a total of 19). 


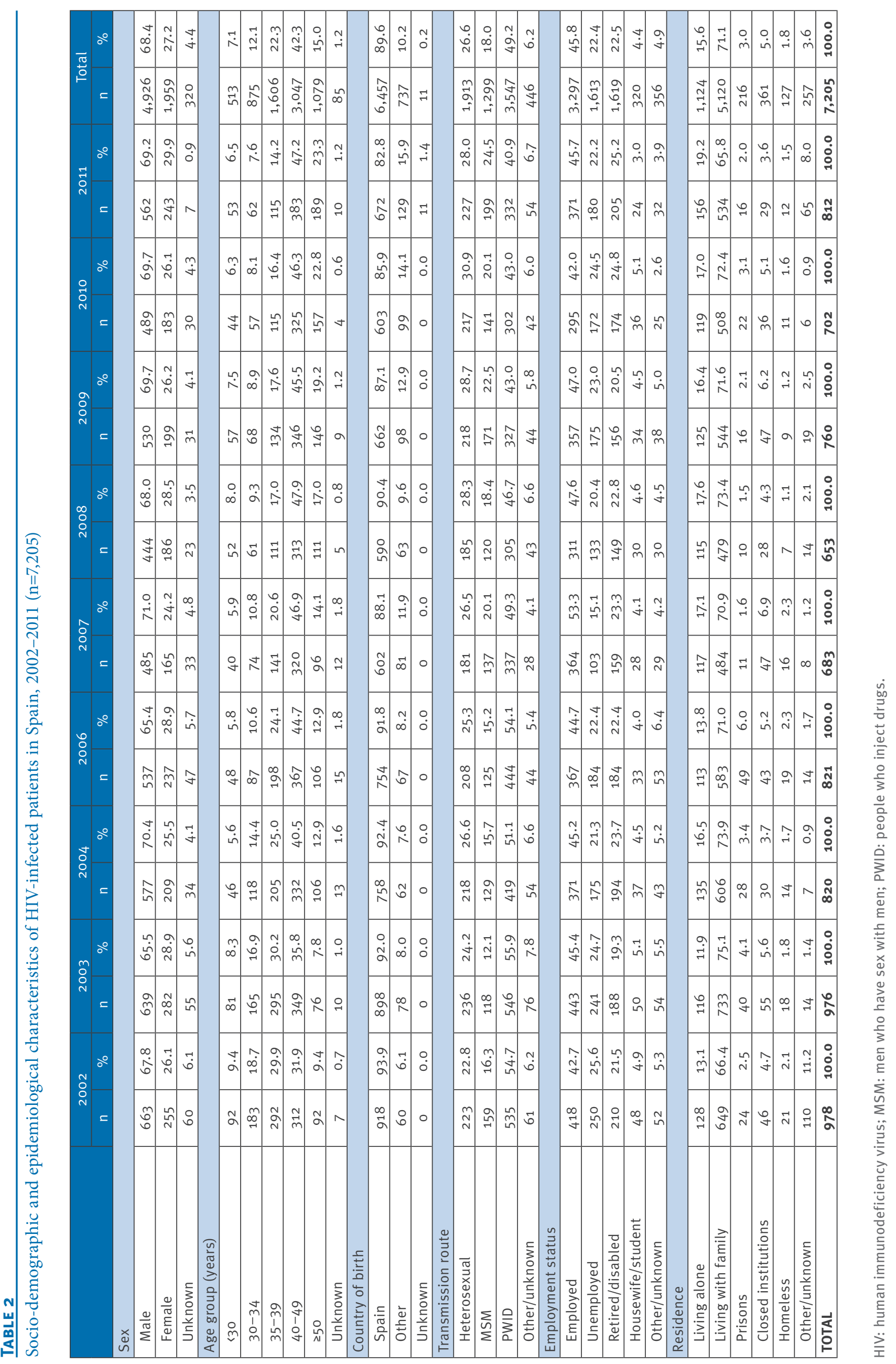




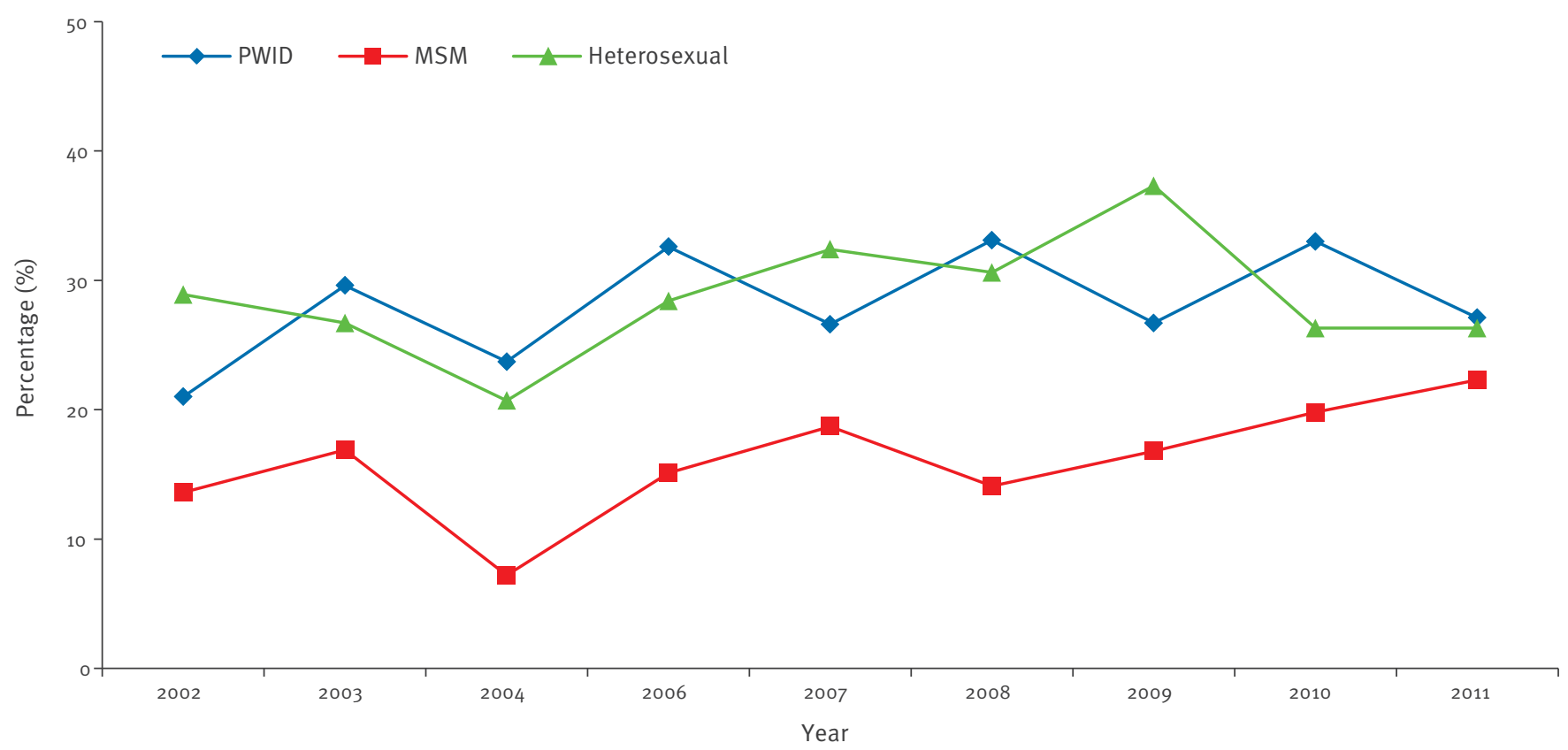

HIV: human immunodeficiency virus; MSM: men who have sex with men; PWID: people who inject drugs.

area. Furthermore, with a few exceptions, antiretroviral drugs are available only in public hospitals, so that the vast majority (more than 95\%) of HIV-infected patients in Spain receive HIV care and treatment in public hospitals.

Participation in the survey is voluntary for both hospitals and individual patients. Between 2002 and 2011 the number of participating hospitals varied from 67 in 2006 (population coverage: $61.3 \%$ of the total population in the participating regions) to 91 in 2011 (population coverage: $72.1 \%$ ), while the total hospitals providing care for HIV patients in the study area ranged from 106 in 2007 to 127 in 2009. The number of participating regions ranged from 13 in 2007 and 2011 to 16 in 2003 (of a total of 19) (Table 1).

In the 2011 survey round, 91 hospitals participated, with an overall population coverage in the participating regions of $72.1 \%$ (ranging from $36 \%$ in the region Madrid to $100 \%$ in the regions Cantabria, Castilla y León, Valencia, Navarra, La Rioja and Melilla). With regard to the whole Spanish population, survey coverage was $38.1 \%$.

Information on the variables of interest was collected in a standard questionnaire by inpatient and outpatient medical staff. All information was extracted from the clinical records, except socio-demographic and behavioural data, which were obtained directly from the patients by the attending physician. The respondent rate varied from a minimum of $86 \%$ in 2009 to a maximum of $93 \%$ in 2010.

Most questions remained the same over the years, but some were excluded, added or modified according to what was deemed necessary at any given time. Once completed, the questionnaires were sent to the National Centre of Epidemiology, where the data were entered into a database and analysed using existing staff resources.

For continuous variables, the mean and its standard deviation were calculated and the t-test was used for comparisons. For categorical variables, distributions were calculated and the chi-squared test was used for comparisons.

The study was performed in accordance with the requirements of the Spanish legislation on data protection. Throughout all study procedures, questionnaires were totally anonymous, i.e. no personal identifiers were collected and linkage of questionnaires to individual patients is not possible.

\section{Results}

From 2002 to 2011 a total of 7,205 PLWH were included in the study, and the majority of them were in ambulatory care, with a proportion increasing from $75.8 \%$ in 2002 to $82.8 \%$ in 2011 . Respondents were predominantly male (between $65.4 \%$ and $71.0 \%$ depending on the year), and their mean age increased steadily over 
Drug injection and participation in a methadone maintenance programme in the 30 days before the survey among current and ex-injecting drug users living with HIV, Spain, 2002-2011 $(n=3,547)$

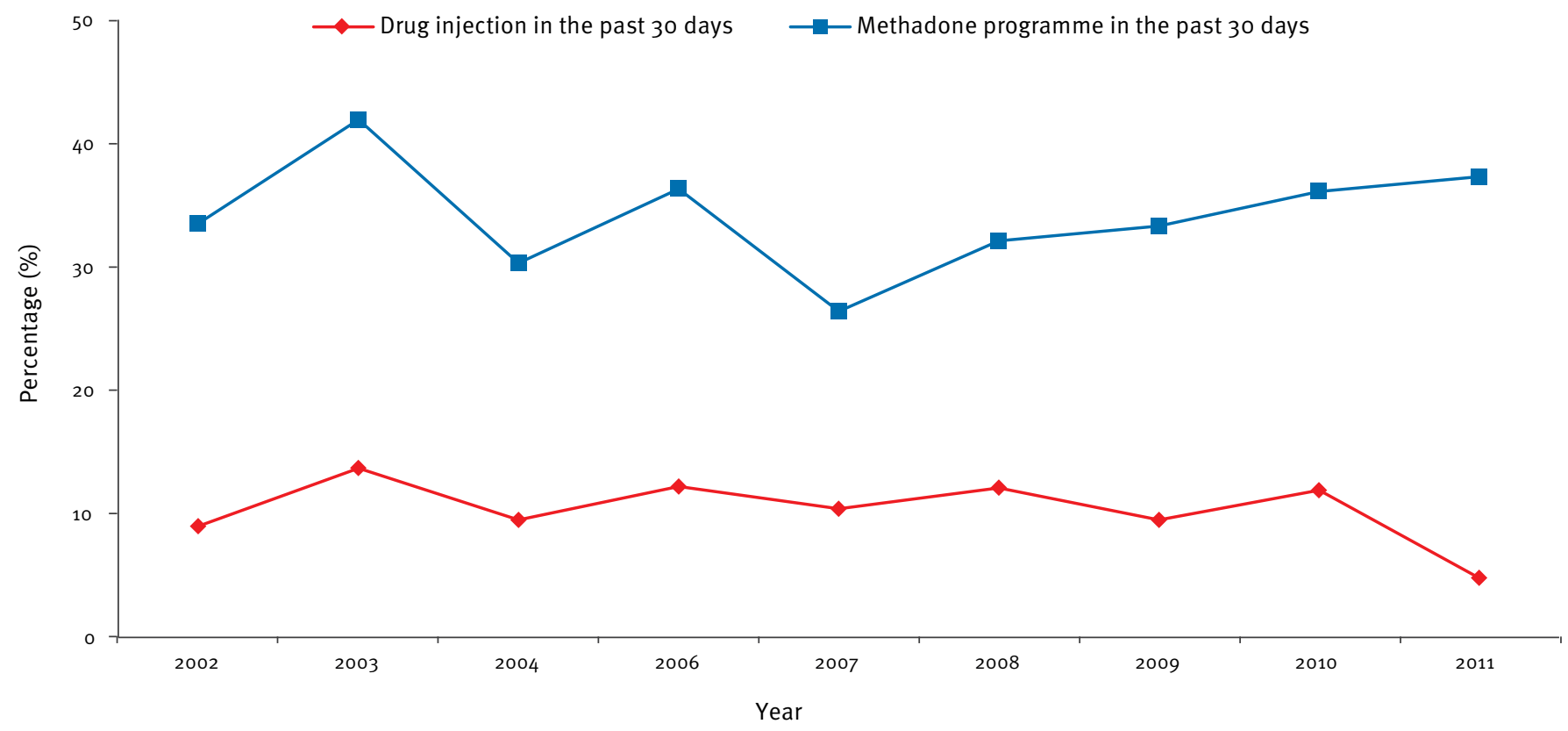

HIV: human immunodeficiency virus.

time, both overall (from 38.7 in 2002 to 43.8 years in 2011) and in all transmission categories, except men who have sex with men (MSM) whose mean age increased until 2006 (from 41.4 to 44.8 years) and remained stable thereafter. The proportion of people born outside Spain also increased significantly over time from $6.1 \%$ in 2002 to $15.9 \%$ in 2011 (p<0.05); in the same period, the proportion of foreign-born among the total Spanish population increased from $6.2 \%$ to $14.2 \%$ [11]. With regard to transmission categories, there has been a clear decrease in the proportion of people infected through injecting drug use while the proportions of MSM and those infected through heterosexual sex have increased. Throughout the study, employment among respondents was low (45.8\%), a significant proportion of patients were living in prison or other closed institutions (3\% and $5 \%$ respectively) and almost $2 \%$ were homeless (Table 2 ).

Overall, six of 10 individuals reported having had sex in the 12 months before the survey, and there was a statistically significant increase in the proportion of people who were sexually active in the age groups between 30 and 34 years (from $63.4 \%$ in 2002 to $85.5 \%$ in 2011) and between 35 and 39 years (from 64.4 in 2002 to $69.6 \%$ in 2012). By sex, there were no differences in the proportion of those reporting sexual intercourse $60.6 \%$ in men vs $62.4 \%$ in women) and no changes were obvious during the period. Overall, $62.5 \%$ of heterosexuals and $64.9 \%$ of MSM reported sexual intercourse in the past 12 months. There was a significant decrease in sexual activity among patients infected through the sharing of injecting equipment (from $60.1 \%$ in 2002 to $55.2 \%$ in 2011; p $<0.05)$. No trend was observed in other risk groups.

Among individuals reporting sex in the 12 months before the survey, the global proportion reporting unprotected intercourse at last sexual encounter has remained stable over time (range: 19.6\%-28.6\%). However, there has been a significant increase ( $p<0.05)$ in unprotected sex at last sexual encounter among individuals aged between 35 and 39 years (from $17.0 \%$ in 2002 to $28.7 \%$ 2011) and between 40 and 49 years (from $17.7 \%$ to $24.6 \%$ ). Similar trends were observed in MSM (from $13.6 \%$ in 2002 to $22.3 \%$ in 2011) and PWID (from $21.0 \%$ in 2002 to $27.1 \%$ in 2011). It is worth noting that although the proportion of unprotected sex among MSM increased, it was still less frequent than in the other two main transmission groups (heterosexual and PWID) (Figure 1).

Since 2011, information has been collected on condom use at last sexual encounter by HIV status of the sexual partner: of 328 patients who, in the previous 12 months, always had sex with partners of serodiscordant/unknown status, $21 \%$ did not use a condom at last sexual encounter, while the corresponding figure among the 112 reporting sex always with HIV-positive partners was $37.5 \%$. Of the remaining 13 subjects who had sex with partners of any status, six did not use a condom at last sexual encounter. 


\section{FIGURE 3}

Proportion of HIV-infected people presenting more than $350 \mathrm{CD} 4 \mathrm{~T}$-cells/mL at last measurement, by transmission category, Spain, 2002-2011 (n=6,759)

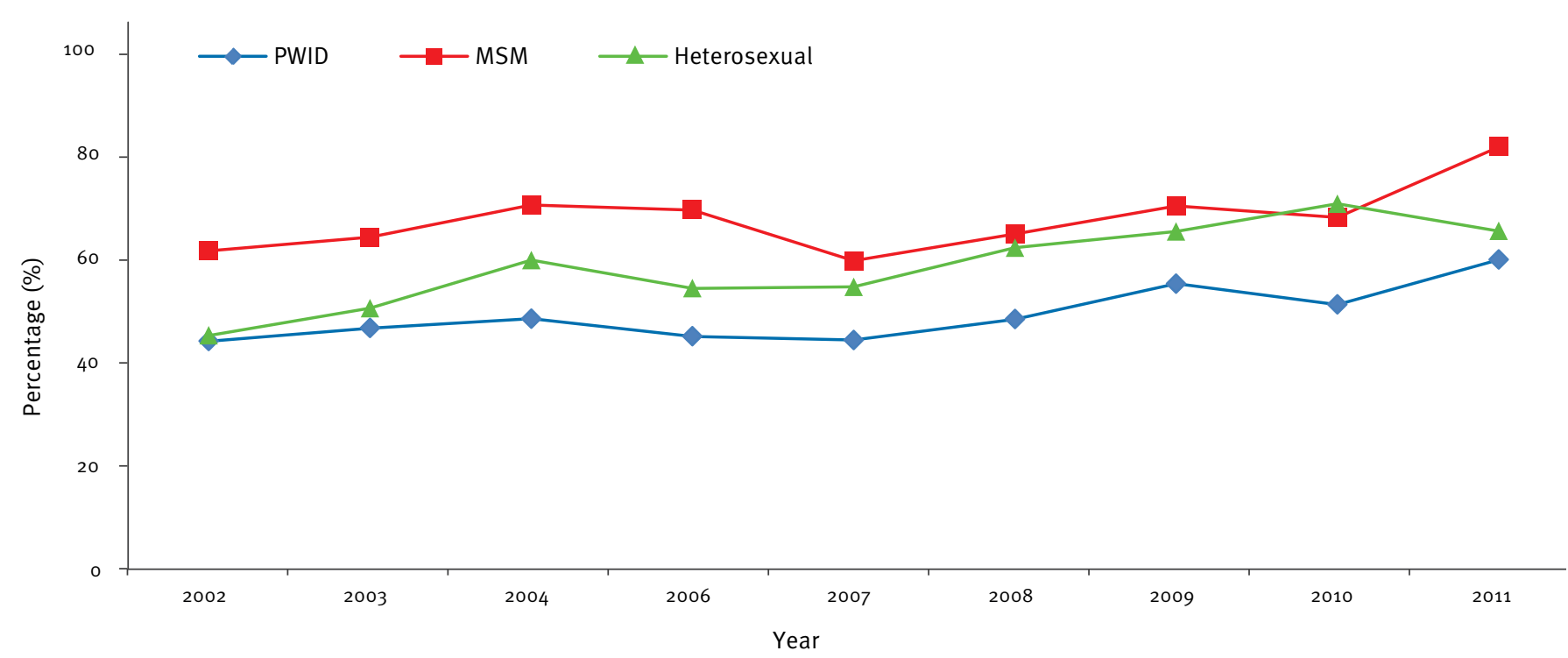

HIV: human immunodeficiency virus; MSM: men who have sex with men; PWID: people who inject drugs.

\section{FIGURE 4}

Proportion of HIV-infected people on antiretroviral treatment with undetectable viral load ( $<200 \mathrm{copies} / \mathrm{mL})$ at last measurement, by transmission category, Spain, 2002-2011 $(n=5,364)$

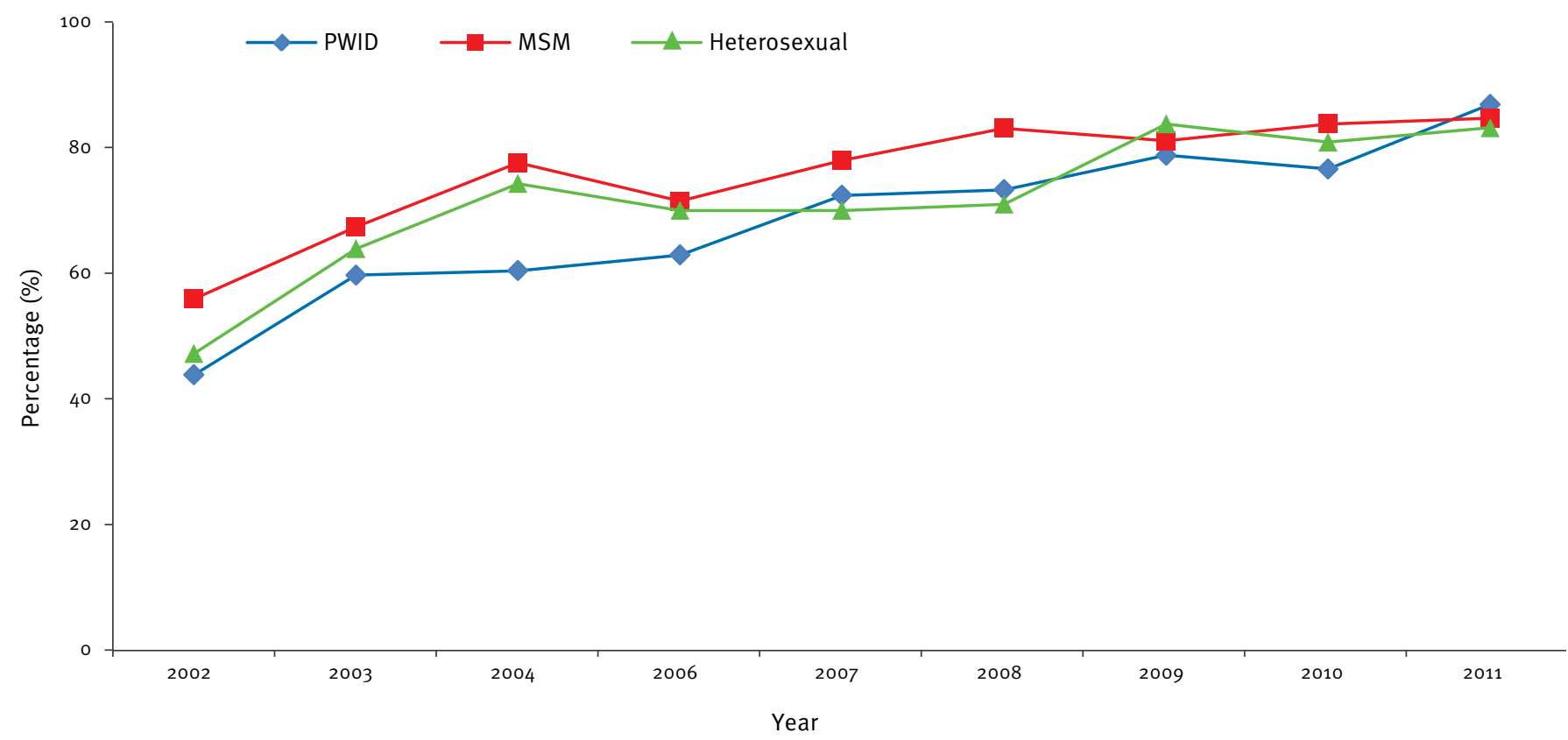

HIV: human immunodeficiency virus; MSM: men who have sex with men; PWID: people who inject drugs. 


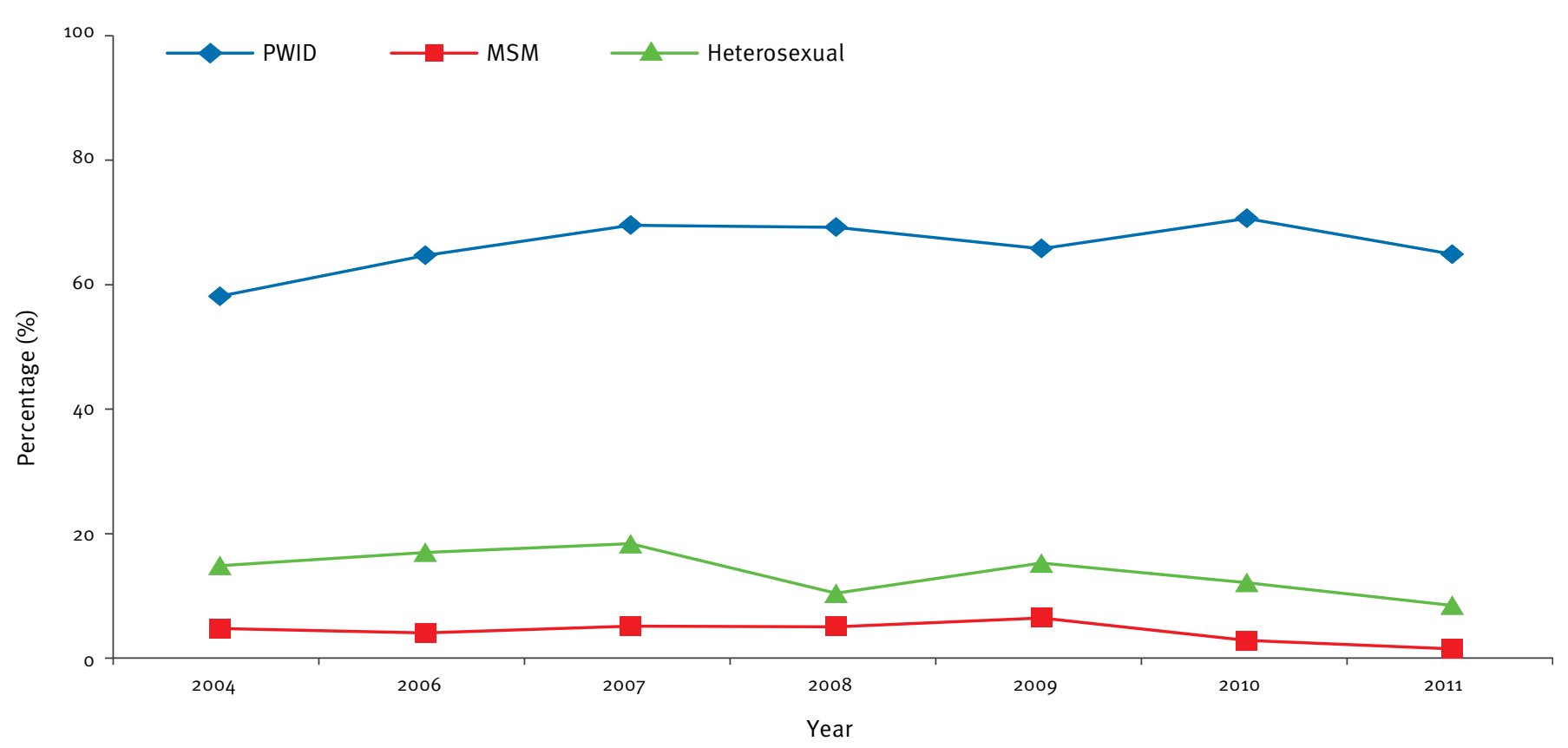

HIV: human immunodeficiency virus; MSM: men who have sex with men; PWID: people who inject drugs.

In $2011,10.5 \%$ of patients reported having been diagnosed with another sexually transmitted infection in the past 12 months, generally syphilis (65\%). Syphilis diagnoses increased from $0.8 \%$ in 2002 to $6.8 \%$ in 2011 ( $p<0.05$ ), and the same trend was observed for gonorrhoea (from $0.1 \%$ to $1.8 \%$, p<0.05).

In patients who acquired the infection through shared injecting equipment, data were collected on drug injection and participation in a methadone maintenance programme (MMP) in the 30 days before the survey. The proportions of respondents reporting drug injection and participation in MMPs both oscillated during the study period, but the changes were not statistically significant: drug injection ranged between a high of $13.7 \%$ in 2003 and a low of $4.8 \%$ in 2011 , while MMP participation ranged between a high of $41.9 \%$ in 2003 and a low of $26.4 \%$ in 2007 (Figure 2).

Overall, $88.2 \%$ of patients in 2011 were receiving antiretroviral treatment (ART) at the time of the survey, compared with $76.0 \%$ in 2002 ( $p<0.05$ ). There were no significant differences in the proportion of respondents on ART by transmission category, and trends followed the same increasing direction as the overall trend. Of the 91 patients who were not on treatment in 2011, 43 (47.3\%) did not meet the clinical criteria [12] to receive it, 37 (40.7\%) did meet them, and 11 (12.1\%) had test results pending. Of the 37 patients who had a treatment indication but were not taking ART, 22 did so following a personal decision, five had interrupted
ART because of toxicity, and in the remaining 10 cases treatment had just been prescribed, they were waiting to recover from another disease before initiating ART or there was no information. Among the 716 PLWH who were in treatment in $2011,560(78.2 \%)$ had optimal adherence according to their physician's judgment.

The most common regime $(290 / 716 ; 40.5 \%)$ prescribed in 2011 comprised two nucleoside reverse transcriptase inhibitors (NRTI) and one non-nucleoside reverse transcriptase inhibitor, and the second most common (277/ $716 ; 38.7 \%)$ consisted of two NRTI and one protease inhibitor.

Between 2002 and 2011, PLWH included in the survey experienced a clear improvement in their health, as reflected by different clinical parameters: the proportion ever diagnosed with acquired immunodeficiency syndrome (AIDS) decreased from 50.9\% to $37.2 \%$ ( $p<0.05)$; the proportion with a CD4 T-cell count greater than 349 cells at last measurement increased from $48.2 \%$ to $66.9 \%$ ( $p<0.05$ ), and similar trends were observed in the three main transmission categories (Figure 3). The proportion of people on ART with suppressed viral load (less than 200 copies) at last measurement increased from $47.0 \%$ in 2002 to $85.2 \%$ in 2011 (p<0.05) (Figure 4). 
The most prevalent co-morbidities in PLWH in the Spanish setting were viral hepatitides, in particular hepatitis B and C. Data collection on hepatitis B and $C$ in the EH began in 2004. In the period from 2004 to 2011, the percentage of persons positive for $\mathrm{HBsAg}$ remained stable (around $4.4 \%$ ), while the percentage of people positive for HCV RNA decreased significantly from $36.0 \%$ to $29.9 \%$; however, when analysing trends by transmission categories, the decrease was observed in heterosexuals but not in PWID or MSM (Figure 5).

Apart from hepatitis, other co-morbidities were evident. In 2011, the most common were: infectious diseases $(n=33,4.1 \%)$, mental disorders $(n=21,2.6 \%)$, respiratory disorders $(n=11,1.3 \%)$ and solid neoplasias $(n=9$, $1.1 \%)$. Lipoatrophy was present in 188 of 812 patients (23.2\%), a higher proportion, although not statistically significant, than the 158 of 820 (19.3\%) notified in 2004 when this information was first collected.

\section{Discussion}

This analysis provides population-based information on PLWH in Spain and presents 10-year trend data for key behavioural and clinical indicators. Our experience with the $\mathrm{EH}$ indicates that it is feasible to systematically perform second generation surveillance on PLWH at low cost and in a sustainable manner. The data collected are useful for identifying changes in epidemiological patterns, for investigating risk behaviours, and for assessing treatment effectiveness and the possible impact of treatment as prevention [4].

The population infected with HIV in Spain has experienced important changes since the 1980 s and $1990 \mathrm{~s}$ with regard to main route of infection and country of origin. Sexual transmission, rather than parenteral transmission through shared injecting equipment, is now the main route of HIV transmission. The proportion of PLWH born outside Spain has also increased sharply. These changes, similar to those revealed in other information systems [13], reflect the impact of measures implemented in response to drug injection in the country [14] and the effect of migration patterns in recent years.

In our study, between $25 \%$ and $30 \%$ of PLWH who had had sex in the 12 months before the survey reported unprotected intercourse in their last sexual encounter. While the overall figure has not changed significantly during the last 10 years, the proportion reporting unprotected sex at last sexual encounter appears to be increasing among PWID and MSM. MSM are overrepresented among new HIV diagnoses in Spain and are the only transmission route with an increasing trend. MSM are also overrepresented in syphilis and gonorrhoea diagnoses performed in a network of STI clinics [15], and outbreaks of hepatitis A, syphilis and lymphogranuloma venereum [16-18] have been described among MSM in recent years. All these facts are in line with our findings and underscore the importance of reinforcing preventive measures in this group.
It is well known that HIV-positive PWID in Spain have poorer adherence to treatment than other HIV-infected patients [19]. In this context, not using condoms could be an additional sign of poorer treatment results, since the same factors of social disadvantage, lack of support and stigma that make PWID less adherent to treatment, could also make them less compliant with preventive measures recommended by their physicians, such as condom use that prevents re-infection with HIV and/or infection with other agents.

Almost $90 \%$ of PLWH in Spain were on ART in 2011, and although the proportion on treatment has always been very high, it has increased further during the last decade. This is likely to be a reflection of the less stringent international criteria to initiate treatment since HIV diagnosis and treatment have during the entire study period been available to anyone in need of it and provided free of charge.

Continued clinical improvement after HAART implementation has been reported in HIV-infected cohorts in Spain [20-22]. Our results confirm these findings and reflect very good treatment effectiveness, confirming that ART is an effective prevention tool. Unfortunately, not all patients have profited equally; poor education and drug use have been found to be important determinants of treatment effectiveness [22,23], and a recent analysis of $\mathrm{EH}$ data showed that regular attendance of HIV clinics, which is likely to be highly correlated with treatment effectiveness, was inversely associated with being homeless, living in institutions, being unemployed, having low educational status and having injected drugs [24]. These results highlight the fact that, even in countries with free access to healthcare and treatment, social determinants play a central role in achieving treatment effectiveness and should be taken into consideration, particularly in a time of economic crisis.

Co-morbidities are a major factor for the quality of life and life expectancy of PLWH. In Spain, due to the central role that injection of drugs had in the initial expansion of the HIV epidemic, hepatitis B and C are the most important co-morbidities, as our results show. Both infections, especially hepatitis $B$, can also be associated to sexual contact, but this association was not present in our data. Vaccination for hepatitis $B$ is available free of charge in Spain during the entire study period, and the proportion reporting vaccination in our study increased from $17.7 \%$ in 2002 to $32.9 \%$ in 2011. The prevalence of active infection with HCV in our study (three of $10 \mathrm{PLWH}$ ) is similar to that found in other studies in Spain [25]. Although treatment for those infections, including liver transplant, is available, hepatopathies are one of the major causes of mortality in HIV-infected people $[26,27]$.

The information system described in this paper has some limitations. Firstly, patients who attend clinics more regularly and/or those who are more seriously 
ill tend to be overrepresented. Secondly, it is possible that patients tend to respond to behavioural questions in a favourable way. Thirdly, questionnaires are administered by many different individuals, making it difficult to control reproducibility and data quality. Fourthly, HIV-infected people who receive care at the participating hospitals for reasons other than HIV are excluded and it is not clear how this could influence the outcomes. Finally, the survey is very sensitive to administrative problems arising on the day of the survey, e.g. a temporary lack of human resources or a strike in the transportation system.

On the other hand, this information system has several strengths. Firstly, it is population-based, allowing all PLWH who attend HIV care in a particular area to participate, rather than those enrolled in cohorts, which often tend to have strict enrolment criteria. Secondly, by providing periodic snapshots across the years it is possible to observe the development of the epidemic over time. Thirdly, clinical staff know the patients and their clinical data very well, allowing them to use existing rapport and clinical knowledge to more easily complete the questionnaire. Last but not least, the entire survey uses existing resources and thus is performed at little to no cost.

\section{Conclusion}

In summary, this hospital-based one-day cross-sectional survey of PLWH allows the collection of second generation surveillance data in this group in Spain. This information is useful to inform preventive policies and to plan services, and allows the assessment of treatment effectiveness and the identification of treatment and prevention barriers.

The results of this analysis have identified areas in which HIV prevention and control in Spain can be further strengthened and provide a model for other countries aiming to implement a low-cost and sustainable system for second generation surveillance among PLWH. While clinical results suggest good treatment effectiveness in our setting, efforts should be made to improve condom use among the patients and to further reduce drug injection.

\section{Members of the Hospital Survey Study Group}

Aragón: M Egido (H.G. San Jorge, Huesca); MP Gracia (H. Obispo Polanco, Teruel); S. Letona (H.C.U. Lozano Blesa, Zaragoza); P Arazo (H.U. Miguel Servet, Zaragoza); R Martínez (H. Royo Villanova, Zaragoza).

Asturias: MJ Tuya (H. San Agustín, Avilés); R Suárez (H. Carmen y Severo Ochoa, Cangas de Nacerca); J Costales (H. de Jarrio, Coaña); ML Garcia-Alcalde (H. de Cabueñes, Gijón); D Escribano (H. de Jove, Gijón); M Rodríguez (H. Valle del Nalón); MT Vázquez (H. Álvarez Buylla, Mieres); V Asensi (H.U. Central de Asturias, Oviedo); A González (H. del Oriente de Asturias, Arriondas).

Baleares: P Fernández H. Can Misses, Ibiza); E García (F.H. Manacor, Manacor); A Payeras (H. Son Llatzer, Palma de
Mallorca); M Riera (H. Son Espases, Palma de Mallorca), R Cantarero (F.H. Comarcal de Inca, Inca); E Rodríguez (H. Mateu Orfila, Mahón).

Canarias: JL Gómez (C.H. U. de Canarias, Tenerife); ME Colino (C.H.U. Materno-Insular Infantil, Las Palmas de Gran Canaria); MA Cárdenas (C.H. Dr. Negrín, Las Palmas de Gran Canaria); M Linares (H.U. Ntra. Sra. de Candelaria, San Cruz de Tenerife); V Pueyo (H.G. de La Palma, La Palma).

Cantabria: MC Fariñas (H.U. Marqués de Valdecilla, Santander); R Teira (H. Sierrallana, Torrelavega); M Carrascosa (H. Comarcal de Laredo, Laredo).

Castilla-La Mancha: E Martínez (C.H.U. de Albacete, Albacete); JL Beato (H. de Hellín, Albacete); H. Portillo (C.H. de Ciudad Real, Ciudad Real); JR Barbera (H.G. La ManchaCentro, Ciudad Real); A López de la Osa (H. Virgen de Altagracia, Ciudad Real); C Pereda (H. Sta. Bárbara, Ciudad Real); P Geijo (H.G. Virgen de la Luz, Cuenca); M Rodríguez (H.U. de Guadalajara, Guadalajara); F Cuadra (H.G. Virgen de la Salud, Toledo); F Marcos (H. Ntra. Sra. del Prado, Toledo).

Castilla y León: MA Garcinuño (H. Ntra. Sra. de Sonsoles, Ávila); JF Lorenzo (H. General Yagüe, Burgos); P Cancelo (H. Santos Reyes, Burgos); M Sánchez (H. Santiago Apóstol, Burgos); JA Carro (C.A de León, León); A Bahamonde (H. El Bierzo, León); J Sánchez, A Alba (C.A. de Palencia, Palencia); M Cordero (H.U. de Salamanca, Salamanca); J Elizaga (C.A de Segovia, Segovia); M del Valle (C.A de Soria, Soria); P Bachiller (H.U. del Río Hortega, Valladolid); C Hinojosa (H.C.U. de Valladolid, Valladolid); F Gamazo (H. Medina del Campo, Valladolid); A Chocarro (C.A de Zamora, Zamora).

Ceuta: L Gonzalez (HU de Ceuta).

Extremadura: A Vera (H. Infanta Cristina, Badajoz); M Galán (H. Don Benito-Villanueva de la Serena, Badajoz); MC Gutiérrez (C.H. Llerena-Zafra, Badajoz); M Medina (H. de Mérida, Badajoz); C Martín (C.H. de Cáceres, Cáceres); J Alonso (H. Virgen del Puerto, Cáceres)

\section{La Rioja: JA Oteo (C.H. San Millán-San Pedro)}

Comunidad de Madrid: J Sanz (H. la Princesa, Madrid); J González-García (H.U. La Paz/IdiPAZ, Madrid); AM Barrios (H. U de Fuenlabrada, Fuenlabrada); S Moreno (H. Ramón y Cajal, Madrid); JF Fabregat (F. Jiménez Díaz, Madrid); P Ryan (H. Infanta Leonor, Madrid); P Miralles (H.G. Gregorio Marañón, Madrid); R Peñalver (H. del Sureste, Arganda del Rey); F Pulido (Hospital Doce de Octubre, Madrid), JE Losa (F. Hospital de Alcorcón, Alcorcón), V Estrada (H.C.U. San Carlos, Madrid); P Martin (H. Carlos III, Madrid); S Arponen (H. de Torrejón, Torrejón); JL Perez (HU Infanta Cristina, Parla); A Portillo (H. Infanta Elena, Valdemoro); R Serrano (H. del Henares, Coslada).

Melilla: A Fernández (H.C. de Melilla).

Murcia: C Toledo (H. Rafael Méndez, Lorca); A Cano (H.G. Universitario de Murcia, Murcia); JA García (H.G. de Área Sta. Ma del Rosell, Cartagena); G Alguacil (H.C. del Noroeste, Caravaca de la Cruz), C Redondo (H.U Virgen de la Arrixaca, Murcia).

Navarra: J Uriz (H. de Navarra).

Comunidad Valenciana: V Giner $(\mathrm{H}$. Virgen de los Lirios, Alicante); JC Blázquez (H. de Torrevieja, Alicante); J Gregori (H. Vega Baja de Orihuela, Alicante); JM Cuadrado (H.U. Sant Joan d'Alacant, Alicante); MI Serrano (H. San Vicente, Alicante); P Martín (H. Marina Alta, Alicante); F Gutiérrez (H.G. Elche, Alicante); R Pascual (H.G. de Elda, Alicante); J Portilla (H.G.U de Alicante, Alicante); F Pascual (H. de 
la Marina Baixa, Alicante); R Hernández (H. del Vinalopó, Alicante); J Usó (H.G. de Castellón, Castellón); V Chabrera (H. de la Plana, Castellón); M Arnal (H.C. de Vinaròs, Castellón); J López-Aldeguer (H.U. la Fe, Valencia); A Artero (H.U. Dr. Pesset, Valencia); E Castellano (H. Pare Jofre, Valencia); I Martínez (H. Lluis Alcanyís, Valencia); C Oltra (H.G. de Requena, Valencia); S Bellver (H. Francesc de Borja, Valencia); C Chazarra (H. Dr. Moliner, Valencia); A Belda (H. de Sagunto, Valencia); B Roig (H. de Manises (Valencia); J Perpiñán (H. de la Ribera, Valencia); I Serra (H. de Mislata, Valencia); MJ Galindo (H. Clínico de Valencia, Valencia); J Flores (H. Arnau de Vilanova, Valencia); E Ortega (Consorcio H.G. de Valencia, Valencia).

\section{Acknowledgments}

The authors are grateful to all patients and clinical staff who have participated in the survey, for their kind collaboration, to Anastasia Pharris for critical review of the manuscript, and to Kathy Fitch for the English review.

\section{Conflict of interest}

None declared.

\section{Authors' contributions}

MD was the main study researcher. She supervised field work and data collection, wrote the statistical analysis plan and the first version of the manuscript. AD did statistical analysis and made important contributions to successive versions of the manuscript. CG performed data collection and management, quality control and reviewed all the manuscript drafts. MP, AT, HM, GG, MCR, JT, GG, RA, AI, LJV, EM, LE, DC, IL were the staff responsible for coordinating the survey in the autonomous regions. They participated in development of the study protocol, supervised field work and estimated the population coverage. They have critically reviewed all versions of the manuscript.

SM, JG-G, AMB, SA, MTG, CR, AC and the Hospital Survey Study Group were the clinicians responsible for patient recruitment the participating hospitals and performed field work in their hospitals. They have reviewed all versions of the paper.

All authors have seen and approved the final manuscript.

\section{${ }^{*}$ Erratum}

The name of A Diaz was left out from the author list on publication. It was added on 23 May 2014. We apologise for this mistake.

\section{References}

1. UNAIDS/WHO Working group on global HIV/AIDS and STI surveillance. Guidelines for second generation HIV surveillance: the next decade. Geneva: World Health Organization; 2000. Contract No.: WHO/CDS/CSR/EDC/2000.5. UNAIDS/00.03E. Available from: http://www.who.int/hiv/pub/ surveillance/pub3/en/

2. Montaner JS, Lima VD, Barrios R, Yip B, Wood E, Kerr T, et al. Association of highly active antiretroviral therapy coverage, population viral load, and yearly new HIV diagnoses in British Columbia, Canada: a population-based study. Lancet. 2010;376(9740):532-9. http://dx.doi.org/10.1016/ So140-6736(10)60936-1

3. Cowan SA, Gerstoft J, Haff I, Christiansen AH, Nielsen J, Obel N. Stable incidence of HIV diagnoses among Danish MSM despite increased engagement in unsafe sex. J Acquir Immune Defic Syndr. 2012;61(1):106-11. http://dx.doi.org/10.1097/ QAl.ob013e31825af890
4. Cohen MS, Chen YQ, McCauley M, Gamble T, Hosseinipour MC, Kumarasamy N, et al. Prevention of HIV-1 infection with early antiretroviral therapy. N Engl J Med. 2011;365(6):493-505. http://dx.doi.org/10.1056/NEJMoa1105243

5. Centers for Disease Control and Prevention (CDC). Vital signs: HIV prevention through care and treatment--United States. MMWR Morb Mortal Wkly Rep. 2011;60(47):1618-23.

6. Gardner EM, McLees MP, Steiner JF, Del Rio C, Burman WJ. The spectrum of engagement in HIV care and its relevance to testand-treat strategies for prevention of HIV infection. Clin Infect Dis. 2011;52(6):793-800. http://dx.doi.org/10.1093/cid/ciq243

7. European Centre for Disease Prevention and Control (ECDC). Mapping of HIV/STI behavioural surveillance in Europe. Stockholm: ECDC; 2009. Available from: http://ecdc.europa. eu/en/publications/publications/ogog ter mapping of hiv sti_behavioural_surveillance_in_europe.pdf

8. UNAIDS report on the global AIDS epidemic 2010. Global report. Geneva: UNAIDS; 2010. UNAIDS/10.11E /JC1958E. Available from: http://www.unaids.org/globalreport/Global_ report.htm

9. Informe nacional sobre los progresos realizados en la aplicación del UNGASS Espa-a. Enero de 2011 - diciembre de 2011 .[National report on the progress achieved in implementing the UNGASS in Spain. January 2011 - December 2011]. Madrid: Ministerio de Sanidad, Servicios Sociales e Igualdad; 2012. Spanish. Available from: http://www.unaids. org/en/dataanalysis/knowyourresponse/countryprogressrepor ts/2012countries/ce_ES_Narrative_Report[1].pdf

10. Grupo de Trabajo de la Encuesta Hospitalaria. [Working Group of the Hospital Survey]. Encuesta hospitalaria de pacientes con VIH/sida. Resultados 2011. Análisis de la evolución 20002011. [Hospital survey of patients with HIV/AIDS. Results 2011. Analysis of the development from 2000 to 2011]. Madrid: Instituto de Salud Carlos III; 2012. Spanish. Available from: http://www.msc.es/ciudadanos/enfLesiones/enfTransmisibles/ sida/vigilancia/InformeEncuestaHospitalaria2011.pdf

11. Instituto Nacional de Estadística (INE). [Spanish National Statistics Institute]. Estadística del Padrón Continuo. [Municipal Register]. Madrid: INE. [Accessed 10 Sep 2013]. Spanish. Available from: http://www.ine.es/jaxi/menu. dotype $=$ pcaxis $\&$ path $=/$ t20/e245/\&file $=$ inebase

12. Panel de expertos de Gesida y Plan Nacional sobre el Sida. [Consensus document of Gesida and Spanish Secretariat for the National Plan on AIDS (SPNS) regarding combined antiretroviral treatment in adults infected by the human immunodeficiency virus (January 2012)]. Enferm Infecc Microbiol Clin. 2012;30(6):e1-89. Spanish.

13. Área de Vigilancia de VIH y Conductas de Riesgo. [HIV surveillance and risk behavioural monitoring Unit]. Vigilancia Epidemiológica del VIH/sida en Espa-a: Sistema de Información sobre Nuevos Diagnósticos de VIH y Registro Nacional de Casos de Sida. [Epidemiological surveillance of HIV/AIDS in Spain: Information system on new HIV diagnoses and national AIDS case registry]. Madrid: Secretaría del Plan Nacional sobre el Sida/Centro Nacional de Epidemiología, 2011. Spanish. Available from: http://www.isciii.es/ISCIII/es/contenidos/ $\mathrm{fd}$-servicios-cientifico-tecnicos/fd-vigilancias-alertas/fdenfermedades/fd-sida/InformeVIHSida_Junio_2011.pdf

14. Torrens M, Fonseca F, Castillo C, Domingo-Salvany A. Methadone maintenance treatment in Spain: the success of a harm reduction approach. Bull World Health Organ. 2013;91(2):136-41. http://dx.doi.org/10.2471/BLT.12.111054

15. Grupo de trabajo sobre ITS. [STI working group]. Diagnósticos de sífilis y gonococia en una red de centros de ITS: características clínico-epidemiológicas. Resultados julio 2005-diciembre 2010. [Diagnoses of syphilis and gonorrhea in a network of STI clinics: clinical and epidemiological characteristics. Results July 2005-December 2010. Madrid: Centro Nacional de Epidemiología; 2012. Spanish. Available from: http://www.msssi.gob.es/ciudadanos/enfLesiones/ enfTransmisibles/sida/vigilancia/InformeEPI_ITS_2005_2010. pdf

16. Tortajada C, de Olalla PG, Pinto RM, Bosch A, Cayla J. Outbreak of hepatitis $A$ among men who have sex with men in Barcelona, Spain, September 2008-March 2009. Euro Surveill. 2009;14(15): $\mathrm{pii}=19175$.

17. Vall-Mayans M, Casals M, Vives A, Loureiro E, Armengol $P$, Sanz B. [Reemergence of infectious syphilis among homosexual men and HIV coinfection in Barcelona, 20022003]. Med Clin (Barc). 2006;126(3):94-6. Spanish. http:// dx.doi.org/10.1157/13083877

18. Vargas-Leguas H, Garcia de Olalla P, Arando M, Armengol $P$, Barbera $M$, Vall $M$, et al. Lymphogranuloma venereum: a hidden emerging problem, Barcelona, 2011. Euro Surveill. 2012;17(2): $\mathrm{pii}=20057$

19. Collazos J, Asensi V, Carton JA. Association of HIV transmission categories with sociodemographic, viroimmunological and 
clinical parameters of HIV-infected patients. Epidemiol Infect. 2010;138(7):1016-24. http://dx.doi.org/10.1017/ So950268809991282

20. del Amo J, del Romero J, Barrasa A, Perez-Hoyos S, Rodriguez C, Diez M, et al. Factors influencing HIV progression in a seroconverter cohort in Madrid from 1985 to 1999 . Sex Transm Infect. 2002;78(4):255-60. http://dx.doi.org/10.1136/ sti.78.4.255

21. Perez-Hoyos S, Ferreros I, del Amo J, Muga R, del Romero J, de Olalla PG, et al. Survival and progression to AIDS in a seroconverter cohort in the post-highly active antiretroviral therapy era: effectiveness goes on. AIDS. 2006;20(2):289-91. http://dx.doi.org/10.1097/01.aids.0000202651.41397.db

22. Sobrino-Vegas $P$, Rodriguez-Urrego J, Berenguer J, Caro-Murillo AM, Blanco JR, Viciana P, et al. Educational gradient in HIV diagnosis delay, mortality, antiretroviral treatment initiation and response in a country with universal health care. Antiv Ther. 2012;17(1):1-8. http://dx.doi.org/10.3851/IMP1939

23. Rodriguez-Arenas MA, Jarrin I, del Amo J, Iribarren JA, Moreno S, Viciana P, et al. Delay in the initiation of HAART, poorer virological response, and higher mortality among HIV-infected injecting drug users in Spain. AIDS Res Hum Retroviruses. 2006;22(8):715-23. http://dx.doi.org/10.1089/aid.2006.22.715

24. Garriga C, Díaz A, Díez M. Determinantes asociados a pacientes con VIH que acuden esporádicamente a revisión en servicios hospitalarios de VIH/sida (Encuesta Hospitalaria). [Determinants associated with HIV patients who present sporadically for review to hospital services for HIV/AIDS (Hospital Survey)]. XIV Congreso Nacional sobre el Sida [XIV National Congress on AIDS]; Zaragoza 2011. Spanish.

25. González-García J, Navarro San Francisco C, Condes E, Díez Romero C, Quereda C, Zamora F, et al, Trends in HCV infection, liver disease severity, and specific treatment modalities among HIV+ patients: Madrid, Spain. 19th CROI; Seattle 2012. Abstract 746.

26. Ferreros I, Lumbreras B, Hurtado I, Perez-Hoyos S, HernandezAguado I. The shifting pattern of cause-specific mortality in a cohort of human immunodeficiency virus-infected and noninfected injecting drug users. Addiction. 2008;103(4):651-9. http://dx.doi.org/10.1111/j.1360-0443.2008.02135.x

27. del Amo J, Perez-Hoyos S, Moreno A, Quintana M, Ruiz I, Cisneros JM, et al. Trends in AIDS and mortality in HIVinfected subjects with hemophilia from 1985 to 2003: the competing risks for death between AIDS and liver disease. Acquir Immune Defic Syndr. 2006;41(5):624-31. http://dx.doi. org/10.1097/01.qai.0000194232.85336.dc 